\title{
Biochemical traits useful for the determination of genetic variation in a natural population of Myracrodruon urundeuva ${ }^{(1)}$
}

\author{
Ludmila Abdala(2), Mario Luiz Teixeira de Moraes $^{(3)}$, Carem Gledes Vargas Rechia(4), Jarbas Francisco Giorgini(2), \\ Marco Eustáquio de Sá( ${ }^{(3)}$ and Maria de Lourdes Teixeira de Moraes Polizeli(5)
}

\begin{abstract}
The objectives of this work were to analyze seeds from 20 trees of aroeira (Myracrodruon urundeuva Fr. All.) of a natural population located in the region of Selvíria, State of Mato Grosso do Sul, Brazil, in order to evaluate their protein, lipid and carbohydrate contents, and to estimate their genetic variation. A completely randomized experimental design consisting of 20 treatments (families) was set up, with two replications. Four types of proteins were detected: albumin (35.0 to $107.3 \mathrm{mg} / \mathrm{g}$ seed), globulin (3.4 to $9.3 \mathrm{mg} / \mathrm{g}$ ), prolamin (60.0 to $135.2 \mathrm{mg} / \mathrm{g}$ ) and glutelin (118.0 to $286.0 \mathrm{mg} / \mathrm{g}$ ). The lipid content varied between 200 and $334 \mathrm{mg} / \mathrm{g}$ seed. The total sugars also varied (26.5 to $46.3 \mathrm{mg} / \mathrm{g}$ seed), with a predominance of polyols (arabinitol, mannitol, glucitol and xylitol). The main monosaccharides detected were glucose and arabinose. Total hydrolysis of the sugars indicated the presence of neutral arabinan and xylan oligosaccharides. The starch content varied from 0.35 to $1.58 \mathrm{mg} / \mathrm{g}$ seed. These biochemical traits showed considerable genetic variability, indicating that only the collection of seeds from many different trees can provide a representative sample of the population for conservation and genetic improvement.
\end{abstract}

Index terms: Myracrodruon urundeuva, seed, proteins, lipids, carbohydrates, evaluation.

Caracteres bioquímicos de interesse para a determinação
da variação genética em uma população natural de aroeira

Resumo - Os objetivos deste trabalho foram analisar sementes de 20 árvores de aroeira (Myracrodruon urundeuva Fr. All.) de uma mesma população na região de Selvíria, MS, quanto ao seu conteúdo de proteínas, lipídios e carboidratos, e os níveis de variação genética existentes em relação a esses compostos. O delineamento experimental usado foi o inteiramente casualizado com 20 tratamentos (famílias) e duas repetições. Foram detectados quatro tipos de proteínas: albumina ( 35,0 a 107,3 mg/g de semente); globulina (3,4 a 9,3 mg/g); prolamina (60,0 a $135,2 \mathrm{mg} / \mathrm{g}$ ) e glutelina $(118,0$ a $286,0 \mathrm{mg} / \mathrm{g})$. Os teores lipídicos apresentaram uma variação de 200 a $334 \mathrm{mg} / \mathrm{g}$ de semente. Os açúcares totais apresentaram uma variação de 26,5 a 46,3 mg/g de semente, com predominância dos polióis: arabinitol, manitol, glucitol e xilitol. Os principais carboidratos detectados foram glicose e arabinose. A hidrólise total dos açúcares indicou a presença de arabinana neutra e oligossacarídeos de xilana. O conteúdo de amido variou entre 0,35 e $1,58 \mathrm{mg} / \mathrm{g}$ de semente. Os caracteres bioquímicos estudados mostraram grande variabilidade genética, indicando que a coleta de sementes em várias árvores constitui uma amostragem mais representativa da população, tanto para fins de conservação como para o melhoramento genético.

Termos para indexação: Myracrodruon urundeuva, semente, proteínas, lipídios, carboidratos, avaliação.

\footnotetext{
(1) Accepted for publication on August 30, 2001. Supported by Fapesp.

(2) Universidade de São Paulo (USP), Fac. de Filosofia, Ciências e Letras de Ribeirão Preto, Av. Bandeirantes, 3900, CEP 14040-901 Ribeirão Preto, SP.

E-mail: mila_abdala@hotmail.com, jarbas@ffclrp.usp.br

(3) Universidade Estadual Paulista, Fac. de Engenharia de Ilha
}

Solteira, Av. Brasil Centro, 56, CEP 15385 Ilha Solteira, SP. E-mail: teixeira@agr.feis.unesp.br, sa@agr.feis.unesp.br (4) USP, Fac. de Ciências Farmacêuticas de Ribeirão Preto, Av. do Café, s/non , CEP 14040-903 Ribeirão Preto, SP. E-mail: cvrechia@fcfrp.usp.br

(5) USP, Fac. de Filosofia, Ciências e Letras de Ribeirão Preto, Dep. de Biologia. Bolsista do CNPq. E-mail: polizeli@ffclrp.usp.br 


\section{Introduction}

The aroeira (Myracrodruon urundeuva Fr. All.), an arborescent species of Anacardiaceae, has a wide geographical distribution which extends from northeastern Brazil to northern Argentina. The wood of this species has a high mechanical resistance and natural durability, a density of $1.19 \mathrm{~g} / \mathrm{cm}^{3}$, and infusions from the plant possess various medicinal properties such as haemostatic and comfort in respiratory and urinary diseases, sore throat and gastritis (Nogueira, 1977; Mainieri et al., 1983; Santin, 1989). Rural populations of Northeast, Southeast and Centre West use the species in such an extent that it is now at risk of extinction.

Knowledge on the chemical composition of fruits and seeds is of fundamental both on diets and other applications. Thus, many researches have been carried out with (on) cereals, legumes, fruits and seeds which are major sources of nutrients in human food. However, the chemical constitution of fruits and seeds of arboreal species is not well known, specially those used for wood extraction. These species are also very important to the survival of the fauna, which inhabits the tropical forests. Moreover, it may serve as source of medicine for population groups. Thus, their seeds or fruits may contain important chemical constituents.

The objectives of this work were to analyze seeds from 20 trees of aroeira for their proteins, lipids and carbohydrates contents, and to estimate their genetic variation.

\section{Material and Methods}

Aroeira seeds were collected in September 1996 of 20 open-pollinated trees from Selvíria, in Mato Grosso do Sul State, Brazil. Since the seeds are intimately associated with the fruit and separation of the two is very difficult, this work was carried out with whole aroeira fruits (fruit + seed). This approach is commonly used for forest species (Figliolia et al., 1993).

\section{Protein}

Proteins were extracted based on their solubility according to Garcia-Agustin \& Primo-Millo (1989). All steps were carried out at $4{ }^{\circ} \mathrm{C}$. The seeds were homogenized $(0.5 \mathrm{~g} / 10 \mathrm{~mL})$ in distilled water (albumin) in a Polytron- type homogenizer at maximum speed for 15 seconds and then extracted consecutively with $5 \%(\mathrm{w} / \mathrm{v})$ sodium chloride (globulin), $60 \%(\mathrm{v} / \mathrm{v})$ ethanol (prolamin) and $0.4 \%(\mathrm{w} / \mathrm{v})$ sodium hydroxide (glutelin). The extracts were centrifuged at $20,000 \mathrm{~g}$ for 20 minutes at $4^{\circ} \mathrm{C}$. An aliquot of each extract was taken and used for protein quantification (Lowry et al., 1951) using bovine serum albumin as a standard.

\section{Soluble sugars}

For the analysis of soluble sugars, the seeds were homogenized $(0.5 \mathrm{~g} / 10 \mathrm{~mL})$ with $80 \%(\mathrm{v} / \mathrm{v})$ ethanol and maintained at $80^{\circ} \mathrm{C}$ for 10 minutes. The cold mixture was centrifuged $(2,000 \mathrm{~g}, 10$ minutes), and the sugars in the supernatant (6A) were determined by the phenolsulphuric method (Dubois et al., 1956) using glucose as a standard. Duplicate samples of the tree with the highest carbohydrate content (tree number 6) were: (i) hydrolyzed, reduced and acetylated; (ii) reduced and acetylated; or (iii) acetylated. Total acid hydrolysis (Mankarios et al., 1979; Selvendran et al., 1979) was performed with $1 \mathrm{M}$ trifluoracetic acid at $100^{\circ} \mathrm{C}$ for 5 hours, followed by reduction with sodium borohydride and acetylation with pyridine-acetic anhydride $\left(1: 1 \mathrm{v} / \mathrm{v}, 15\right.$ hours, $\left.25^{\circ} \mathrm{C}\right)$. The resulting alditol acetates were analyzed by gas-liquid chromatography (GLC; GC-14A Shimadzu chromatograph) with $3 \%$ of $O V-225$ column $(0.2 \mathrm{~cm}$ i. d. x $170 \mathrm{~cm})$ and a Gas Chrom Q support at $170^{\circ} \mathrm{C}$. The carrier gas was nitrogen $\left(30 \mathrm{~mL} \mathrm{~min}^{-1}\right)$.

\section{Uronic acids}

Uronic acids were determined by the m-hydroxybiphenyl method (Blumenkrantz \& AsboeHansen, 1973) using glucuronic acid (1 mg/mL) as standard.

\section{Starch}

Starch was determined by a modification of the method described by Rick \& Stegbauer (1974). The precipitated material obtained following extraction with boiling $80 \%$ ethanol was washed twice with distilled water, suspended in $3 \mathrm{~mL} 0.1 \mathrm{M} \mathrm{KOH}$, and the mixture boiled for $15 \mathrm{~min}-$ utes to solubilize the starch. After adjusting the $\mathrm{pH}$ to 6.5 , $7 \mathrm{~mL} 50 \mathrm{mM}$ sodium acetate buffer, $\mathrm{pH}$ 6.0, containing $10 \mathrm{mM} \mathrm{NaCl}$ was added and the mixture was incubated for 24 hours under continuous agitation at $60^{\circ} \mathrm{C}$ in the presence of $2 \mathrm{~mL}$ fungal glucoamylase (Cereia et al., 2000). The mixture was boiled for 5 minutes and centrifuged $(1,200 \mathrm{~g}, 15$ minutes). The precipitate was washed twice and the supernatants combined. The glucose formed was quantified by the glucose oxidase method (Bergmeyer \& Bernt, 1974) using a kit from Labtest (Brazil). 


\section{Lipid}

The lipid fraction was extracted according to Radin (1969). Seeds were homogenized $(0.5 \mathrm{~g} / 10 \mathrm{~mL})$ in chloroform:methanol $(2: 1 \mathrm{v} / \mathrm{v})$ and the mixture centrifuged at $2,000 \mathrm{~g}$ for 5 minutes at room temperature. The supernatant was removed and the precipitate re-extracted with chloroform:methanol. The supernatants were combined and an equal volume of $2.0 \mathrm{M} \mathrm{KCl}$ added. After separation of the phases, the organic phase was transferred to a previously weighed beaker and the aqueous phase re-extracted with the same volume of chloroform:methanol. The organic phases were combined, evaporated at $37^{\circ} \mathrm{C}$ and the amount of lipids determined by the difference in mass. All reagents were of the best commercially available quality.

A completely randomized design with 20 treatments (families) with two replications was used in this work. Each family was represented for $0.5 \mathrm{~g}$ of aroeira seeds. Estimates of variance components for all random effects were obtained by equating observed mean squares to their expected values. The variance component of open-pollinated half-sib families was assumed to estimate one quarter of the additive genetic variance. After variance, components were obtained from analysis of variance (Table 1). The genetic parameters was calculated according to Vencovsky \& Barriga (1992): (a) among families means heritability: $\hat{\mathrm{h}}_{\mathrm{m}}^{2}=\hat{\sigma}_{\mathrm{p}}^{2} /\left(\hat{\sigma}_{\mathrm{p}}^{2}+\left(\hat{\sigma}^{2} / \mathrm{r}\right)\right)$; (b) genetic coefficient: $\mathrm{CV}_{\mathrm{g}}=100 . \hat{\sigma}_{\mathrm{p}} / \hat{\mathrm{m}}$ and (c) ratio: $\hat{b}=\mathrm{CV}_{\mathrm{g}} / \mathrm{CV}$, were $\hat{\sigma}_{\mathrm{p}}^{2}=$ variance due to differences among families; $\hat{\sigma}^{2}=$ variance due to error; $r=$ number of replication; $\mathrm{CV}=$ coefficient of variation.

Path-coefficient analysis using estimates of genetic correlation and their evolution in direct and indirect effects was done to examine in detail the effects of each constituent, including protein fractions, relative to the total protein content. Path-coefficient analysis was according to Cruz \& Regazzi (1994), using the GENES program developed by Cruz (1997).

\section{Results and Discussion}

Significant differences among seeds were detected for all substances, indicating that there is genetic variation within the population studied (Table 2). The starch content was evaluated in only a single sample (no statistical analysis), though the results clearly showed variation in this trait among the Selvíria aroeira seeds, perhaps because the population was of wild origin. The coefficient of variation was less than $10 \%$ for all of the investigated traits.
There was a predominance of protein $(36.3 \%)$ followed by lipids $(26.5 \%)$, with soluble sugar (3.5\%) and starch $(0.1 \%)$ representing small proportions; unidentified substances accounted for about $15.2 \%$ of the total material (Table 3). The separation of proteins into fractions according to their solubility indicated that there was a predominance of glutelins (53.2\%) followed by prolamins (25.5\%) and albumins (19.8\%); globulins accounted for only a minor portion $(1.5 \%)$ of the total protein content.

It is uncertain whether the amounts recorded for these fractions truly reflect the protein reserve present in embryonic tissue (cotyledons), or if other parts of the seeds or of the fruits may also have contributed to the final result. Glutelins, which are the main reserve proteins in monocotyledons but uncommon in dicotyledons (Bewley \& Black, 1978, 1982, 1994; Mayer \& Poljakoff-Mayber, 1989), predominated in M. urundeuva seeds. Other dicotyledon species which exhibit significant amounts of glutelins in their seeds include Nicotiana sp. (Mayer \& Poljakoff-Mayber, 1989), Castanea sativa, C. crenata (Collada et al., 1986) and Euphorbia heterophylla (Suda \& Giorgini, 2000). In Nicotiana sp. and in both species of Castanea, glutelins represent $50 \%$ and $30 \%$, respectively, of the total seed protein. Prolamins are generally absent in the seeds of dicotyledons, occurring only in the gramineae (Shewry et al., 1995). On the other hand, the occurrence of globulins is very common in the seeds of dicotyledons (Müntz, 1996) and the seeds of M. urundeuva had a very low amount of this fraction. The foregoing comparisons refer mainly to cereal and leguminous seeds, since there are no data for the fruits or seeds of forest trees.

After proteins, the lipid fraction is the next most important constituent of aroeira seeds (Table 3). The constitution of this fraction was not investigated in detail, however, the predominant lipids in the seeds

Table 1. Expected mean squares for the analysis of variance.

\begin{tabular}{lcc}
\hline Source & $\mathrm{DF}$ & Expected mean squares \\
\hline Family & $(\mathrm{p}-1)$ & $\sigma^{2}+\mathrm{r} \cdot \sigma_{\mathrm{p}}^{2}$ \\
Error & $\mathrm{p}(\mathrm{r}-1)$ & $\sigma^{2}$ \\
\hline Total & $\mathrm{pr}-1$ & \\
\hline
\end{tabular}


are triglycerides containing unsaturated fatty acids (Carvalho \& Nakagawa, 1983). In some species which are known to be rich in lipids, such as Macadamia ternifolia, Bertholletia excelsa, Corylus avellana, Elaeis guineensis and Euphorbia heterophylla, lipids constitute more than $50 \%$ of the seed dry weight (Bewley \& Black, 1978; Suda \& Giorgini, 2000). Medeiros (1996) observed means of $28.0 \%$ up to $35.6 \%$ oil content in the seeds of $M$. urundeuva collected in Northeast Brazil.

The content of soluble sugars in M. urundeuva seeds was very low when compared to the other constituents. Soluble sugars are generally not the main carbohydrate seed reserve (Bewley \& Black, 1994) and in many cases constitute less than $10 \%$ of the dry mass, as has been shown for several species (Juliano \& Varner, 1969; Palmiano \& Juliano, 1972; Ferreira et al., 1979; Umezurike \& Numfor, 1979; Adams et al., 1980; Cardemil \& Reinero, 1982; Steadman et al., 1996). In contrast, higher levels of these sugars have been found in embryos, such as in corn where sucrose accounts for $17 \%$ of the embryonic dry mass (Williams \& Leopold, 1989) and in Euphorbia heterophylla where the soluble sugars account for about $12 \%$ of the dry mass (Suda \& Giorgini, 2000).

The soluble ethanol fraction of sugar was not the most representative in the aroeira, but was nevertheless analyzed (Table 4 ). In progeny number 6 , the carbohydrates were mostly of the neutral type (95.9\%), only $4.1 \%$ being uronic acids. Seeds were extracted with ethanol, resulting in two fractions (6A and 6B). The polyols, arabinitol, glucitol, mannitol and xylitol were detected in 6A and 6B by gas-liquid chromatography, in the molecular ratios of 59:23:15:3 (6A) and 55:22:20:3 (6B). The reducing monosaccharides in the same fractions were also determined by GLC (Table 4) and included arabinose, glucose, mannose, xylose and rhamnose. The principal compounds were glucose $(78 \% ; 6 \mathrm{~A})$ and arabinose $(44 \%$;

Table 2. Chemical composition of seeds (mg/g) from a population of Myracrodruon urundeuva from Selvíria, MS.

\begin{tabular}{rrrrrrrrr}
\hline Family & Albumin & Globulin & Prolamin & Glutelin & $\begin{array}{c}\text { Total } \\
\text { protein }\end{array}$ & Lipid & $\begin{array}{c}\text { Soluble } \\
\text { sugar }\end{array}$ & Starch \\
\hline 1 & 84.8 & 7.63 & 132.0 & 286.0 & 510.5 & 289.0 & 36.3 & 0.72 \\
2 & 95.6 & 9.22 & 68.7 & 134.2 & 307.6 & 207.5 & 30.2 & 0.86 \\
3 & 35.0 & 3.37 & 108.8 & 192.8 & 340.0 & 200.0 & 41.5 & 0.88 \\
4 & 71.2 & 6.13 & 84.0 & 118.1 & 279.4 & 269.5 & 33.6 & 1.58 \\
5 & 85.2 & 6.94 & 104.8 & 159.9 & 356.8 & 247.0 & 29.3 & 0.78 \\
6 & 70.6 & 4.80 & 115.7 & 156.2 & 347.3 & 305.5 & 46.3 & 0.46 \\
7 & 70.2 & 5.30 & 135.2 & 220.0 & 430.7 & 225.0 & 41.8 & 0.59 \\
8 & 41.5 & 4.46 & 83.6 & 230.5 & 360.1 & 242.5 & 39.3 & 0.35 \\
9 & 107.3 & 4.51 & 92.5 & 204.7 & 409.0 & 268.0 & 27.8 & 0.39 \\
10 & 70.7 & 4.30 & 92.7 & 204.9 & 372.6 & 289.5 & 26.6 & 0.61 \\
11 & 67.6 & 5.45 & 103.0 & 236.8 & 412.8 & 334.5 & 35.3 & 1.08 \\
12 & 55.7 & 5.57 & 100.1 & 192.9 & 354.2 & 243.0 & 27.3 & 0.95 \\
13 & 44.0 & 5.24 & 77.6 & 207.0 & 333.9 & 238.5 & 37.1 & 1.01 \\
14 & 80.2 & 6.18 & 92.2 & 218.7 & 397.3 & 251.5 & 33.8 & 1.07 \\
15 & 68.1 & 3.65 & 64.3 & 169.6 & 305.6 & 262.6 & 40.0 & 0.44 \\
16 & 57.8 & 7.37 & 83.2 & 246.7 & 395.0 & 267.5 & 43.2 & 0.35 \\
17 & 93.7 & 4.84 & 94.9 & 264.9 & 458.3 & 317.5 & 26.6 & 0.80 \\
18 & 60.9 & 7.14 & 59.7 & 196.0 & 323.7 & 240.0 & 34.1 & 0.57 \\
19 & 70.5 & 3.42 & 80.7 & 125.7 & 280.4 & 309.5 & 31.8 & 1.00 \\
20 & 104.9 & 5.55 & 80.3 & 136.8 & 327.5 & 283.0 & 28.5 & 1.08 \\
\hline Mean & 71.8 & 5.56 & 92.7 & 195.1 & 365.1 & 264.6 & 34.5 & 0.78 \\
SE & 4.9 & 0.31 & 4.1 & 10.1 & 14.1 & 16.7 & 2.4 & 0.31 \\
F & 16.2 & 23.62 & 24.1 & 21.4 & 17.7 & 4.6 & 6.2 & - \\
Pr>F & 0.0001 & 0.0001 & 0.0001 & 0.0001 & 0.0001 & 0.0006 & 0.0001 & - \\
CV $(\%)$ & 9.7 & 8.0 & 6.3 & 7.3 & 5.5 & 8.9 & 9.9 & - \\
\hline & & & & & & & &
\end{tabular}


$6 \mathrm{~B})$. The increase in arabinose and xylose concentrations after the low-molecular mass carbohydrate from fractions 6A and 6B were hydrolyzed strongly suggests the presence of arabinan and xylan oligosaccharides in aroeira seeds. Analyses of low molecular mass carbohydrates demonstrated that aroeira seeds are a potential source of arabinan and xylan oligosaccharides. Arabinan oligosaccharides have been used to generate monoclonal antibodies specific for the linear chain of arabinan (Willats et al., 1998). These findings could provide an important tool for localizing arabinans or xylans in plant tissues or cell cultures (Tables 2 and 3 ). The main carbohydrate detected in the insoluble material was starch, although it occurred in low amounts $(0.08 \%)$

Table 3. Mean values of chemical composition of Myracrodruon urundeuva seeds.

\begin{tabular}{lrcr}
\hline Compounds $^{(1)}$ & $\%$ & Protein fractions $^{(2)}$ & $\%$ \\
\hline Total protein & 36.3 & Glutelins & 53.2 \\
Lipids & 26.5 & Prolamins & 25.5 \\
Sugar & 3.5 & Albumins & 19.8 \\
Starch & 0.1 & Globulins & 1.5 \\
Others & 15.2 & - & - \\
\hline
\end{tabular}

(1) The components are expressed as a percentage of the whole seed weight

(2) The protein fractions are expressed as percentages of the total protein indicating that starch is not an important constituent in aroeira seeds. These findings contrasts with other species which are important sources of starch.

High values of heritability on a family mean bases indicate a strong genetic effect on these traits (Table 5). Although comparison between aroeira and other data in literature is difficult, moderate to high estimates of heritability in the oil content of soybean seeds have been reported (Miranda et al., 1998). The ratio (b) was greater than 1.0 for all of the traits, indicating that these traits are not influenced very much by the environment and could be used in breeding programs (Vencovsky \& Barriga, 1992). Genetic variability (CVg) remained greater than $20 \%$ for each protein fraction, followed by the soluble sugar and lipid fractions. These findings suggest that more detailed studies on protein variability in aroeira seeds are important in order to guarantee the genetic variability and conservation of aroeira populations.

The genetic correlation between biochemical variables and the total protein showed medium to high averages for prolamins and glutelins, low values for lipids, albumins, and globulins, and no relation with the soluble sugars (Table 6). The largest observed direct effect was for glutelin relative to the total protein content. The indirect effects of the soluble sug-

Table 4. Composition of monosaccharides of Myracrodruon urundeuva seeds.

\begin{tabular}{|c|c|c|c|c|c|c|c|}
\hline \multirow[t]{2}{*}{ Fractions } & \multirow{2}{*}{$\begin{array}{c}\text { Neutral } \\
\text { sugar }(\mathrm{g} \%)\end{array}$} & \multirow{2}{*}{$\begin{array}{l}\text { Uronic acid } \\
\qquad(\mathrm{g} \%)\end{array}$} & \multicolumn{5}{|c|}{ Neutral monosaccharides $(\mathrm{g} \%)^{(1)}$} \\
\hline & & & Arabinose & Glucose & Manose & Rhamnose & Xylose \\
\hline $6 \mathrm{~A}$ & 96.1 & 3.9 & 14.4 & 78.0 & 4.6 & - & - \\
\hline $6 \mathrm{~B}$ & 95.7 & 4.3 & 44.4 & 40.1 & 9.0 & 3.4 & 3.1 \\
\hline
\end{tabular}

(1) As alditol acetates on a column of OV-225.1.

Table 5. Estimates of some genetic parameters for biochemical traits in Myracrodruon urundeuva seeds.

\begin{tabular}{|c|c|c|c|c|c|c|c|}
\hline Parameters $^{(1)}$ & Albumin & Globulin & Prolamin & Glutelin & Total protein & Lipid & $\begin{array}{c}\text { Soluble } \\
\text { sugar }\end{array}$ \\
\hline & ------------ & --------- & - & $---(\mathrm{mg} / \mathrm{g}$ & ------. & - & -------- \\
\hline$\hat{\sigma}_{\mathrm{a}}^{2}$ & $1,476.6$ & 8.93 & $1,554.00$ & $8,341.5$ & $1,3297.8$ & 0.004 & 30.63 \\
\hline$\hat{\mathrm{h}}_{\mathrm{m}}^{2}$ & 0.94 & 0.96 & 0.96 & 0.95 & 0.94 & 0.79 & 0.84 \\
\hline$\hat{\mathrm{b}}$ & 2.76 & 3.36 & 3.40 & 3.19 & 2.89 & 1.35 & 1.61 \\
\hline $\mathrm{CV}_{\mathrm{g}}(\%)$ & 26.8 & 26.9 & 21.3 & 23.4 & 15.8 & 12.1 & 16.0 \\
\hline
\end{tabular}

${ }^{(1)} \hat{\mathrm{h}}_{\mathrm{m}}^{2}$ : Heritability estimates in the narrow sense; $\mathrm{CVg}(\%)$ : genetic coefficient of variation in $\%$; $\hat{\sigma}_{\mathrm{a}}^{2}$ : genetic additive variance estimate; $\hat{\mathrm{b}}$ : ratio between $\mathrm{CVg} / \mathrm{CV}$. 
Table 6. Results of path-coefficient analysis of the direct and indirect genetic associations of six biochemical traits with total protein content.

\begin{tabular}{lcccccc}
\hline Correlation & Albumin & Globulin & Prolamin & Glutelin & $\begin{array}{c}\text { Soluble } \\
\text { sugar }\end{array}$ & Lipid \\
\hline $\begin{array}{l}\text { Due to direct effects } \\
\text { Due to indirect effects }\end{array}$ & 0.35 & 0.02 & 0.34 & 0.80 & 0.01 & -0.01 \\
$\quad$ Via albumin & - & 0.11 & 0.00 & -0.05 & -0.21 & 0.14 \\
$\quad$ Via globulin & 0.01 & - & 0.00 & 0.00 & 0.00 & -0.01 \\
$\quad$ Via prolamin & 0.00 & -0.02 & - & 0.13 & 0.09 & 0.05 \\
$\quad$ Via glutelin & -0.13 & 0.05 & 0.32 & - & 0.09 & 0.17 \\
$\quad$ Via soluble sugar & -0.01 & 0.00 & 0.00 & 0.00 & - & 0.00 \\
$\quad$ Via lipid & 0.00 & 0.00 & 0.00 & 0.00 & 0.00 & - \\
\hline Total genetic correlations & 0.22 & 0.16 & 0.66 & 0.88 & -0.02 & 0.34 \\
\hline
\end{tabular}

ars and of the lipids relative to the correlation between the total proteins and to the different types of proteins were practically zero. Therefore, the correlation between the soluble sugars and the lipids in relation to the total proteins had an important indirect effect on albumins, glutelins, and prolamins, and the indirect effect on globulins which was neutral.

\section{Conclusions}

1. These biochemical traits show considerable genetic variability, indicating that only the collection of seeds from many different trees can provide a representative sample of the population for conservation and genetic improvement of the aroeira.

2. The main chemical component of aroeira seeds is protein $36.3 \%$ (glutelins, prolamins, albumins and globulins) followed by lipids (26.5\%), with soluble sugar $(3.5 \%)$ and starch $(0.1 \%)$; unidentified substances accounted for about $15.2 \%$ of the total material.

3. Aroeira seeds are a potential source of arabinan and xylan oligosaccharides.

4. Genetic variability $(\mathrm{CVg})$ remains greater than $20 \%$ for each protein fraction, followed by the soluble sugar and lipid fractions; the results show variation in this trait among the Selvíria aroeira seeds.

\section{Acknowledgements}

To Conselho Nacional de Desenvolvimento Científico e Tecnológico (CNPq) and Fundação de Amparo à Pesquisa do Estado de São Paulo (Fapesp) for the financial support; to Mauricio de Oliveira, Amauri Ramos Pinhal, Ricardo Alarcon (Departamento de Biologia, FFCLRP, USP) and Mrs. Selma Maria Bozzite de Moraes (Departamento de Fitotecnia, FEIS, Unesp) for technical assistance.

\section{References}

ADAMS, C. A.; RINNE, R. W.; FJERSTAD, M. C. Starch deposition and carbohydrase activities in developing and germinating soya seeds. Annals of Botany, London, v. 45, p. 577-582, 1980.

BERGMEYER, H. V.; BERNT, E. Methods of enzymatic analysis. New York: Bergmeyer, 1974. p. 1205-1214.

BEWLEY, J. D.; BLACK, M. Physiology and biochemistry of seeds in relation to germination. Berlin: Springer, 1978. v. 1, p. 7-37.

BEWLEY, J. D.; BLACK, M. Physiology and biochemistry of seeds in relation to germination. Berlin: Springer, 1982. v. 2.

BEWLEY, J. D.; BLACK, M. Seeds: physiology of development and germination. 2. ed. New York: Plenum, 1994. p. 1-31.

BLUMENKRANTZ, N.; ASBOE-HANSEN, G. New method for quantitative determination of uronic acids. Analytical Biochemistry, Duluth, v. 54, p. 484-489, 1973.

CARDEMIL, L.; REINERO, A. Changes of Araucaria araucana seed reserves during germination and early seedling growth. Canadian Journal of Botany, Ottawa, v. 60, p. 1629-1638, 1982. 
CARVAlho, N. M.; NAKAGAWA, J. Semente: ciência, tecnologia e produção. Campinas: Fundação Cargill, 1983. 429 p.

CEREIA, M.; TERENZI, H. F.; JORGE, J. A.; GREENE, L. J.; ROSA, J. C.; POLIZELI, M. L. T. M. Glucoamylase activity from the thermophilic fungus Scytalidium thermophilum: biochemical and regulatory properties. Journal of Basic Microbiology, Berlin, v. 40, p. 83-92, 2000.

COLLADA, C.; CASADO, R.; BARBER, D.; FERNANDEZ DE CALEYA, R.; ARAGONCILLO, C. Characterization of seed protein fractions from Castanea spp. Journal of Experimental Botany, Oxford, v. 37, p. 1872-1878, 1986.

CRUZ, C. D. Programa GENES: aplicativo computacional em genética e estatística. Viçosa, MG: Imprensa Universitária, 1997. 442 p.

CRUZ, C. D.; REGAZZI, A. J. Modelos biométricos aplicados ao melhoramento genético. Viçosa, MG: Imprensa Universitária, 1994. 390 p.

DUBOIS, M.; GILlES, K. A.; HAMILTON, J. K.; REBERS, P. A.; SMITH, F. Colorimetric method for determination of sugar and related substances. Analytical Chemistry, Washington, v. 28, p. 350-356, 1956.

FERREIRA, A. G.; DIETRICH, S. M. C.; HANDRO, W. Changes in the metabolism of Araucaria angustifolia during the early phases of germination and growth. Revista Brasileira de Botânica, São Paulo, v. 2, p. 67-71, 1979.

FIGLiOLIA, M. B.; OLIVEIRA, E. C.; PIÑARODRIGUES, F. C. M. Análise de sementes. In: AGUIAR, I. B.; PIÑA-RODRIGUES, F. C. M.; FIGLIOLIA, M. B. (Ed.). Sementes florestais tropicais. Brasília: Associação Brasileira de Tecnologia de Sementes, 1993. p. 137-174.

GARCIA-AGUSTIN, P.; PRIMO-MILLO, E. Ultrastructural and biochemical changes in cotyledon reserve tissues during germination of citrus seeds. Journal of Experimental Botany, Oxford, v. 40, p. 383-390, 1989.

JULIANO, B. O.; VARNER, J. E. Enzymatic degradation of starch granules in the cotyledonous of germinating peas. Plant Physiology, Bethesda, v. 44, p. 886-892, 1969.

LOWRY, O. H.; ROSEBROUGH, N. J.; FARR, A. L.; RANDALL, R. J. Protein measurement with the folin phenol reagent. Journal of Biological Chemistry, Bethesda, v. 193, p. 265-275, 1951.
MAINIERI, C.; CHIMELO, J. P.; ALFONSO, V. A. Manual de identificação das principais madeiras comerciais brasileiras. São Paulo: Companhia de Promoção de Pesquisa Científica e Tecnológica do Estado de São Paulo, 1983. 418 p.

MANKARIOS, A. T.; JONES, C. F. G.; JARVIS, M. C.; THRELFALL, D. R.; FRIEND, J. Hydrolysis of plant polysaccharides and g. 1. c. analysis of their constituent neutral sugars. Phytochemistry, Oxford, v. 18, p. 189197, 1979.

MAYER, A. M.; POLJAKOFF-MAYBER, A. The germination of seeds. Oxford: Pergamon, 1989. p. 23-37.

MEDEIROS, A. C. S. Comportamento fisiológico, conservação de germoplasma a longo prazo e previsão de longevidade de sementes de aroeira (Astronium urundeuva (Fr. All.) Engl.). 1996. 127 f. Tese (Doutorado) - Universidade Estadual Paulista, Jaboticabal.

MIRANDA, Z. F. S.; ARIAS, C. A. A.; TOLEDO, J. F. F.; OLIVEIRA, M. F. Soybean seed oil content: genetic control under different photoperiods. Genetics and Molecular Biology, Ribeirão Preto, v. 21, p. 387-394, 1998.

MÜNTZ, K. Proteases and proteolytic cleavage of storage proteins in developing and germinating dicotyledonous seeds. Journal of Experimental Botany, Oxford, v. 47 , p. $605-622,1996$.

NOGUEIRA, J. C. B. Reflorestamento heterogêneo com essências indígenas. São Paulo: Instituto Florestal, 1977. p. 17-19.

PALMIANO, E.; JULIANO, B. Biochemical changes in the rice grain during germination. Plant Physiology, Bethesda, v. 49, p. 751-756, 1972.

RADIN, N. S. Preparation of lipid extracts. New York: Academic, 1969. p. 245-254. (Methods in enzymology, 14).

RICK, W.; STEGBAUER, H. P. $\alpha$-Amylase measurements of reducing groups. In: BERGMEYER, H. V.; GAWEN, K. (Ed.). Methods of enzymatic analysis. New York: Academic, 1974. p. 885-890.

SANTIN, D. A. Revisão taxonômica do gênero Astronium Jacq. e reavaliação do gênero Myracrodruon Fr. Allem. (Anacardiaceae). 1989. 178 f. Dissertação (Mestrado) - Universidade Estadual de Campinas, Campinas. 
SELVENDRAN, R. R.; MARCH, J. F.; RING, S. G. Determination of aldoses and uronic acid content of vegetal fiber. Analytical Biochemistry, Duluth, v. 96, p. 282-292, 1979.

SHEWRY, P. R.; NAPIER, J. A.; TATHAM, A. S. Seed storage protein: structures and biosynthesis. Plant Cell, Baltimore, v. 7, p. 945-956, 1995.

STEADMAN, K. J.; PRITCHARD, H. W.; DEY, P. M. Tissue-specific soluble sugars in seeds as indicator of storage category. Annals Botany, London, v. 77, p. 667-674, 1996.

SUDA, C. N. K.; GIORGINI, J. F. Seed reserve composition and mobilization during germination and initial seedling development of Euphorbia heterophylla. Brazilian Journal of Plant Physiology, Londrina, v. 12, p. 226244, 2000. Special edition.
UMEZURIKE, G. M.; NUMFOR, F. A. Changes in the content of starch and activities of some enzymes of carbohydrate metabolism in cotyledonous of germinating seeds of Voandzeia subterranea. Journal of Experimental Botany, Oxford, v. 30, p. 583-588, 1979.

VENCOVSKY, R.; BARRIGA, P. Genética biométrica no fitomelhoramento. Ribeirão Preto: Sociedade Brasileira de Genética, 1992. 496 p.

WILLATS, W. G.; MARCUS, S. E.; KNOX, J. P. Generation of monoclonal antibody specific to (1-5)-alpha-Larabinan. Carbohydrate Research, Amsterdam, v. 308, p. 149-152, 1998.

WILLIAMS, R. J.; LEOPOLD, A. C. The glassy state in corn embryos. Plant Physiology, Bethesda, v. 89, p. 977981, 1989. 